\title{
Highly Active Aluminosilicates with a Hierarchical Porous Structure for Acetalization of 3,4-dimethoxybenzaldehyde
}

\author{
Hartatia,b,c, Didik Prasetyoko $^{b^{*}}$, Mardi Santosoc, Hasliza Bahrujid, Sugeng Triwahyono ${ }^{\mathrm{e}}$ \\ ${ }^{a}$ Department of Chemistry, Faculty of Science and Technology, Universitas Airlangga, Surabaya, 60115, Indonesia \\ ${ }^{b}$ Laboratory of Material Chemistry and Energy, Department of Chemistry, Faculty of Mathematics and Natural Sciences, Institut Teknologi Sepuluh \\ Nopember, Surabaya, 60111, Indonesia \\ 'Laboratory of Natural Products and Chemical Synthesis, Department of Chemistry, Faculty of Mathematics and Natural Sciences, Institut Teknologi \\ Sepuluh Nopember, Surabaya, 60111, Indonesia \\ ${ }^{d}$ Cardiff Catalysis Institute, School of Chemistry, Cardiff University, Cf10 3AT, United Kingdom \\ elbnu Sina Institute for Fundamental Science Studies, Universiti Teknologi Malaysia, Johor Bahru, Malaysia \\ *Corresponding author: didikp@chem.its.ac.id; didik.prasetyoko@gmail.com
}

\section{Article history}

Received :5 March 2014

Received in revised form:

19 April 2014

Accepted :3 May 2014

\section{Graphical abstract}

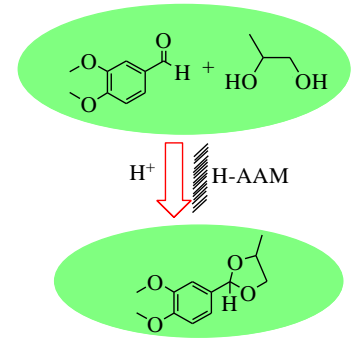

\section{Abstract}

We report the synthesis of highly active mesoporous aluminosilicate for the acetalization of 3,4dimethoxybenzaldehyde with propylene glycol. The existing synthesis methods for aluminosilicate and ZSM-5 were modified to produce aluminosilicate material with hierarchical porous structure. A combination of two structure directing agents, tetrapropylammonium hydroxide (TPAOH) and cetyltrimethylammonium bromide $(\mathrm{CTAB})$, produced a highly active aluminosilicate framework that provides a wide access for bulky reactants and strong acid sites to catalyse the reaction. The pore structure and the strength of the acid sites were crucial for high conversion of 3,4-dimethoxybenzaldehyde.

Keywords: Hierarchical porous aluminosilicate; acetalization; 3,4-dimethoxybenzaldehyde

\begin{abstract}
Abstrak
Kami melaporkan hasil sintesis aluminosilikat mesopori dengan aktiviti tinggi untuk asetalisasi 3,4dimetoksi benzaldehida dengan propilena glikol. Kaedah sintesis aluminosilikat dan ZSM-5 yang telah sedia ada dimodifikasi sehingga menghasilkan material aluminosilikat dengan struktur liang hierarki. Kombinasi kedua-dua sebatian pengarah struktur, iaitu tetrapropilamonium hidroksida (TPAOH) dan setiltrimetilamonium bromida (CTAB), telah menghasilkan kerangka aluminosilikat dengan aktiviti tinggi kerana memberikan kemudahan akses bagi reaktan bermolekul besar dan tapak asid yang kuat sebagai mangkin tindak balas. Struktur liang dan tapak asid yang kuat merupakan faktor yang penting untuk menghasilkan konversi yang tinggi dari 3,4-dimetoksi benzaldehida.
\end{abstract}

Kata kunci: Aluminosilikat berliang hierarki; asetalisasi; 3,4-dimetoksibenzaldehida

(C) 2014 Penerbit UTM Press. All rights reserved.

\subsection{INTRODUCTION}

Acetalization reaction between aldehyde and alcohol is an important process in industry and has been widely used to produce active additives in fragrances. The unique chemical structure in acetal compound plays an important role as protecting agent in organic synthesis [1]. The industrial needs of acetal compound, especially to be used as additive in fragrances, has prompted this study to find alternative ways for designing a simpler synthesis approach and environmentally friendly catalysts [2].

Currently, acetal compound is produced largely from glycol/diol [1-4]; propylene glycol [1,5]; glycerol/triol $[1,3,6,10,11]$; methanol [7-9,12]; 2-ethyl hexanol [13]; and pentaerythritol [14] by using protic acid catalysts such as hydrochloric acid, sulfuric acid, and $p$-toluenesulfonic acid (PTSA) [15]. Although the activity of the catalysts is significantly higher, it still suffers from the common problems caused by homogeneous catalysts such as a tedious process for product purification and a large amount of acidic waste that can cause severe environmental pollutions including corrosion to chemical plants [1]. Zeolites [1,16] and molecular sieves [6,7] have been identified as a potential heterogeneous acid catalysts for such reaction. Aluminosilicate material was explored as active catalyst to drive the reaction where researches have been focused only on porous aluminosilicate catalysts [16]. However, the lack of interest in amorphous materials has prompted this study to explore the real potential of this material. We modified 
the existing recipe for the preparation of ZSM-5 and aluminosilicate by combining two structure directing agents to create a hierarchical material with high acid strength. The catalyst was used for acetalization of 3,4dimethoxybenzaldehyde with propylene glycol.

\subsection{EXPERIMENTAL}

\subsection{Chemicals}

Tetraethyl orthosilicate (TEOS, $\geq 99 \%$ ), sodium aluminate $\left(\mathrm{Al}_{2} \mathrm{O}_{3} \quad 50-56 \%\right)$, sodium hidroxide $(\geq 98 \%)$, and tetrapropylammonium hydroxide (TPAOH, $1 \mathrm{~L}=1.00 \mathrm{~kg}, 40 \mathrm{wt}$ $\%$ solution in water), 3,4-dimethoxybenzaldehyde $\geq 98 \%$, propylene glycol $(\geq 99 \%)$, toluene $(\geq 99.9 \%)$, and nitrobenzene ( $\geq 99 \%$ ) were purchased from Merck; while hexadecyltrimethyl ammonium bromide (CTAB) were purchased from AppliChem. All the chemicals were used as received without further purification.

\subsection{Synthesis of Catalysts}

Hierarchical porous aluminosilicate catalyst (AAM) was prepared by modification of the method for the synthesis of mesoporous ZSM-5 [17] and mesoporous titanosilicates [18], with a molar composition of $1 \mathrm{SiO}_{2}: 0.0125 \mathrm{Al}_{2} \mathrm{O}_{3}: 0.2 \mathrm{TPAOH}$ $: 38 \mathrm{H}_{2} \mathrm{O}$. Sodium aluminate was dissolved in a solution of TEOS by stirring for $30 \mathrm{~min}$. TPAOH and water were added into the reaction mixture and stirred for another $15 \mathrm{~h}$ at room temperature. The mixture was then transferred into a polypropylene autoclave and heated at $80{ }^{\circ} \mathrm{C}$ for $24 \mathrm{~h}$. CTAB, used as a mesophase forming agent (a molar ratio of $\mathrm{SiO}_{2} / \mathrm{CTAB}=3.85$ ), was added after the reaction mixture was cooled at room temperature with gentle stirring for $30 \mathrm{~min}$. The mixture was then aged at room temperature for $3 \mathrm{~h}$. The solid was separated from the supernatant by centrifugation and washed with distilled water until the $\mathrm{pH}$ of the supernatant was 7. Finally, the solid was dried at $60{ }^{\circ} \mathrm{C}$ for $24 \mathrm{~h}$ and calcined at $550{ }^{\circ} \mathrm{C}$ for $1 \mathrm{~h}$ in $\mathrm{N}_{2}$ and $6 \mathrm{~h}$ in air to remove any organic compounds. Another type of amorphous mesoporous aluminosilicate (AAM-T) was prepared using the similar procedure but TPAOH was replaced with $\mathrm{NaOH}$. Microporous ZSM-5 (ZSM-5 type zeolite) was synthesized according to the procedures by Cheng et al. [19] and TPAB was used as structure-directing agents (SDA).

In order to produce hydrogen formed catalysts, all the synthesis products were treated with ammonium acetate solution $(0.5 \mathrm{~mol} / \mathrm{L})$ at $60{ }^{\circ} \mathrm{C}$ for $3 \mathrm{~h}$. The solids were centrifuged and washed thoroughly with distilled water before drying overnight at $110{ }^{\circ} \mathrm{C}$ and calcined at $550{ }^{\circ} \mathrm{C}$ for $1 \mathrm{~h}$ in $\mathrm{N}_{2}$ and $6 \mathrm{~h}$ in air.

\subsection{Characterization}

Powder X-ray diffraction (XRD) patterns of the solids samples were collected on Philips X'pert XRD instrument with $\mathrm{Cu} \mathrm{K \alpha}$ radiation with a step size of $0.02^{\circ}$ and counting time of $10 \mathrm{~s}$. The samples were grinded in agate mortar before analysis. Data were recorded in the $2 \theta$ range of $5-50^{\circ}$.

Fourier transform infrared (FTIR) spectra of the samples were recorded on a Shimadzu spectrophotometer using the $\mathrm{KBr}$ pellet technique, in the range of $400-4000 \mathrm{~cm}^{-1}$ with a spectral resolution of $4 \mathrm{~cm}^{-1}, 45$ scans, at $20^{\circ} \mathrm{C}$.

Spectra of pyridine adsorbed on the samples also were recorded on the same spectrometer for acidity study. Before measurement of pyridine adsorption, the samples were pressed to thin wafers (around $10 \mathrm{mg} / \mathrm{cm}^{2}$ ) and placed into a sample holder. The sample disks were evacuated at $400{ }^{\circ} \mathrm{C}$ for $4 \mathrm{~h}$ in the $\mathrm{N}_{2}$ and cooled to room temperature. Then 2 drops of pyridine was exposed near the disks at room temperature. After the adsorption at room temperature for $1 \mathrm{~h}$ the infrared spectra were recorded. The desorption procedure were conducted at 150 and $300{ }^{\circ} \mathrm{C}$ for $3 \mathrm{~h}$ in order to determine the acidity of Lewis and Brønsted acid sites by evaluating the amount of remaining adsorbed pyridine as temperature increases. The concentrations of Brønsted (B) and Lewis (L) acid sites were calculated from the peak areas of adsorbed pyridine at around 1540 and 1450 $\mathrm{cm}^{-1}$, using $\varepsilon(\mathrm{B})$ and $\varepsilon(\mathrm{L})$ extinction coefficients of 1.88 and $1.42 \mathrm{~cm} \cdot \mathrm{mmol}^{-1}$, respectively [20].

Nitrogen physisorption isotherms were collected on a Quantachrome Nova version 10.01. The materials were degassed for $5 \mathrm{~h}$ at $300{ }^{\circ} \mathrm{C}$, prior to analysis. Brunauer, Emmett, and Teller (BET) calculations were used to determine the material surface area. Mesopore size distributions were calculated using the Barrett, Joyner, and Halenda (BJH) method.

\subsection{Catalytic Performance}

Acetalization reactions of 3,4-dimethoxybenzaldehyde by propylene glycol was performed in a $50 \mathrm{~mL}$ three-necked roundbottom flask [1], using a Dean Stark apparatus to remove the water formed during the reaction. About $1.12 \mathrm{mmol}$ of 3,4dimethoxybenzaldehyde, $2.15 \mathrm{mmol}$ of propylene glycol, $0.02 \mathrm{~g}$ of dried catalyst and toluene $(20 \mathrm{~mL})$ were refluxed by oil bath at $106{ }^{\circ} \mathrm{C}$ for $4 \mathrm{~h}$. Samples were taken at regular time periods and analyzed by Techcomp 7900 gas chromatography equipped with HP 88 column and FID detector. The products were also further identified using gas chromatography-mass spectrometer. The conversion of 3,4-dimethoxybenzaldehyde (substrate) and the selectivity of products were calculated based on equation (1) and (2), respectively $[11,21]$.

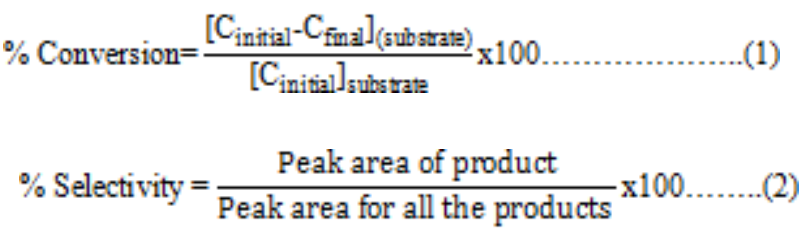

Where $\mathrm{C}$ is concentration of the respective species in the reaction mixture.

\subsection{RESULTS AND DISCUSSION}

\subsection{Characterization of the Catalysts}

Figure 1 shows the XRD patterns of the amorphous aluminosilicate (AAM) synthesized using TPAOH and CTAB as the structure directing agents and the XRD patterns for AAM$\mathrm{T}$ and ZSM-5 samples. Generally, it is clear that the addition of TPAOH on the aluminosilicate synthesis mixture does not alter the amorphous characteristics of aluminosilicate materials as only negligible diffraction lines were observed from the XRD pattern. However, there is very small peak at around $2 \theta=22^{\circ}$, that might be due to the appearance of a crystalline ZSM-5 phase in the AAM sample. ZSM-5 sample showed high intensity of the diffraction lines as indication for high crystallinity of the sample. 


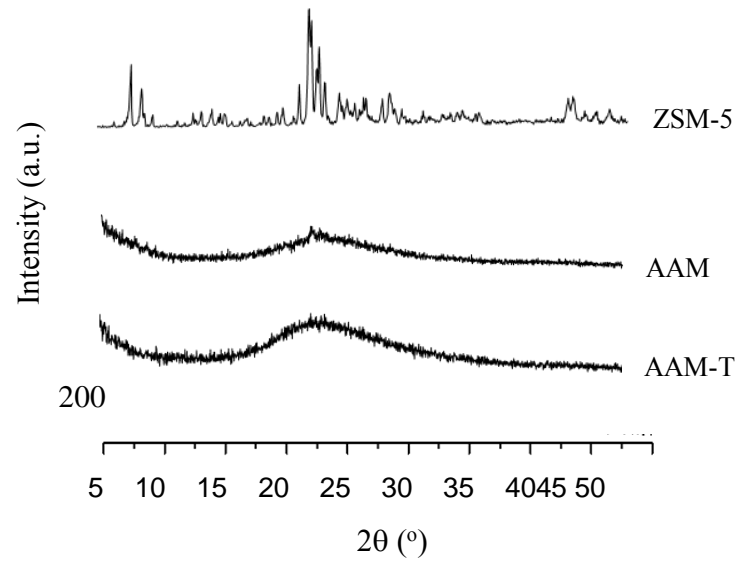

Figure 1 XRD patterns of AAM-T, AAM and ZSM-5

The infrared spectra of aluminosilicates framework vibration in the range of $1400-400 \mathrm{~cm}^{-1}$ are shown in Figure 2. ZSM-5's infrared spectrum was also included as comparison. Interpretations of these spectra were based on the assignment of the infrared bands of the structural groups in the material framework. The absorption bands at around $1222 \mathrm{~cm}^{-1}$ (external asymmetric stretching), $1000-1200 \mathrm{~cm}^{-1}$ (internal asymmetric stretching), $795 \mathrm{~cm}^{-1}$ (external symmetric stretching), and 445 $\mathrm{cm}^{-1}$ (T-O bending) are observed in the amorphous materials (AAM-T and AAM) and these characteristics are insensitive to the structural changes $[22,23]$. The infrared spectra of AAM and AAM-T also contained a shoulder band at around $980 \mathrm{~cm}^{-1}$ attributed to the terminal silanol group on the wall surface of the mesoporous materials [22]. The additional small band at around $545 \mathrm{~cm}^{-1}$ was only observed for the AAM sample. This band is characteristic of MFI type zeolite that arised from the double rings lattice vibration of the framework (Figure 2, arrow). Meanwhile, for ZSM-5, the framework vibration at around 1230 and $545 \mathrm{~cm}^{-1}$ are characteristic of the MFI-type zeolite structure and are sensitive to structural changes [23].

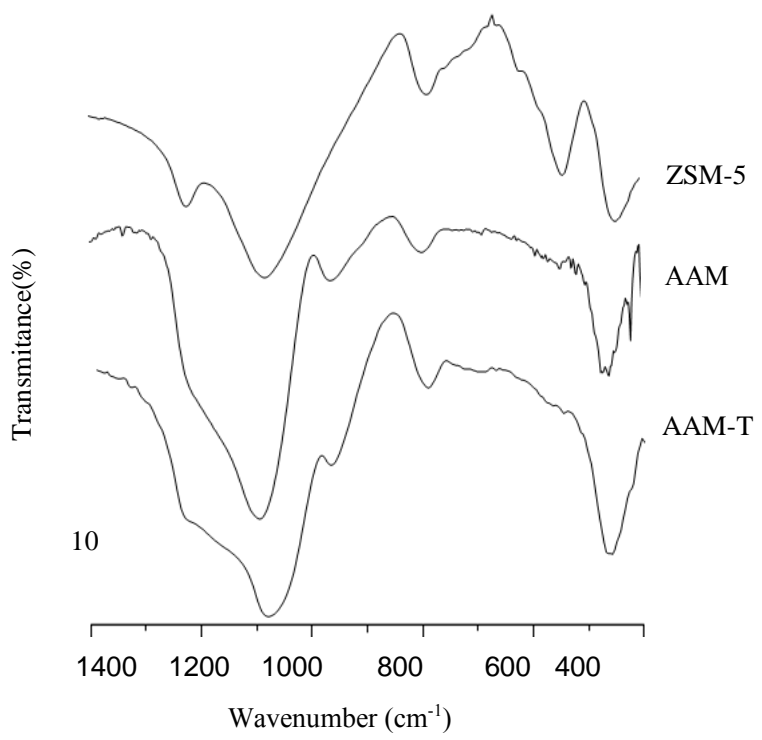

Figure 2 FTIR spectra of AAM-T, AAM and ZSM-5
Figure 3 shows the $\mathrm{N}_{2}$ adsorption-desorption isotherm of AAMT, AAM and ZSM-5 samples. According to the IUPAC classification [24], the adsorption-desorption isotherm with a very high adsorption at low relative pressure and an almost flat hysteresis loop appearing at $P / P o>0.10$ is typical characteristic of type I for microporous solids and this can be seen on ZSM-5. The adsorption-desorption isotherms of the AAM and AAM-T show a typical pattern of type IV structure with AAM showing an $\mathrm{H} 1$ hysteresis loop. The pore structure parameters were calculated according to the mathematical models from the $\mathrm{N}_{2}$ adsorption-desorption isotherms and the data are given in Table 1. The surface area of microporous structure of ZSM-5 is very high at around $250 \mathrm{~m}^{2} / \mathrm{g}$. However, this material does not possess a mesoporous structure which can be seen by only 5.77 $\mathrm{m}^{2} / \mathrm{g}(2.2 \%$ of total surface area) and $0.01 \mathrm{cc} / \mathrm{g}$ of mesopores surface area and pore volume detected. The AAM-T however contains a mesopores with high surface area and pore volume at around $278.77 \mathrm{~m}^{2} / \mathrm{g}(97.9 \%)$ and $0.44 \mathrm{cc} / \mathrm{g}$, respectively. Meanwhile, AAM produced both mesoporous and microporous structure. The surface area of mesopore was found at about $145.99 \mathrm{~m}^{2} / \mathrm{g}$, which is almost half as compared to microporous structure. It is interesting to note that AAM also has a high pore volume (ca. $0.31 \mathrm{cc} / \mathrm{g}$ ). This finding proved that AAM has hierarchical porous structure that will allow a good accesability for a relatively large molecular size of reactant.
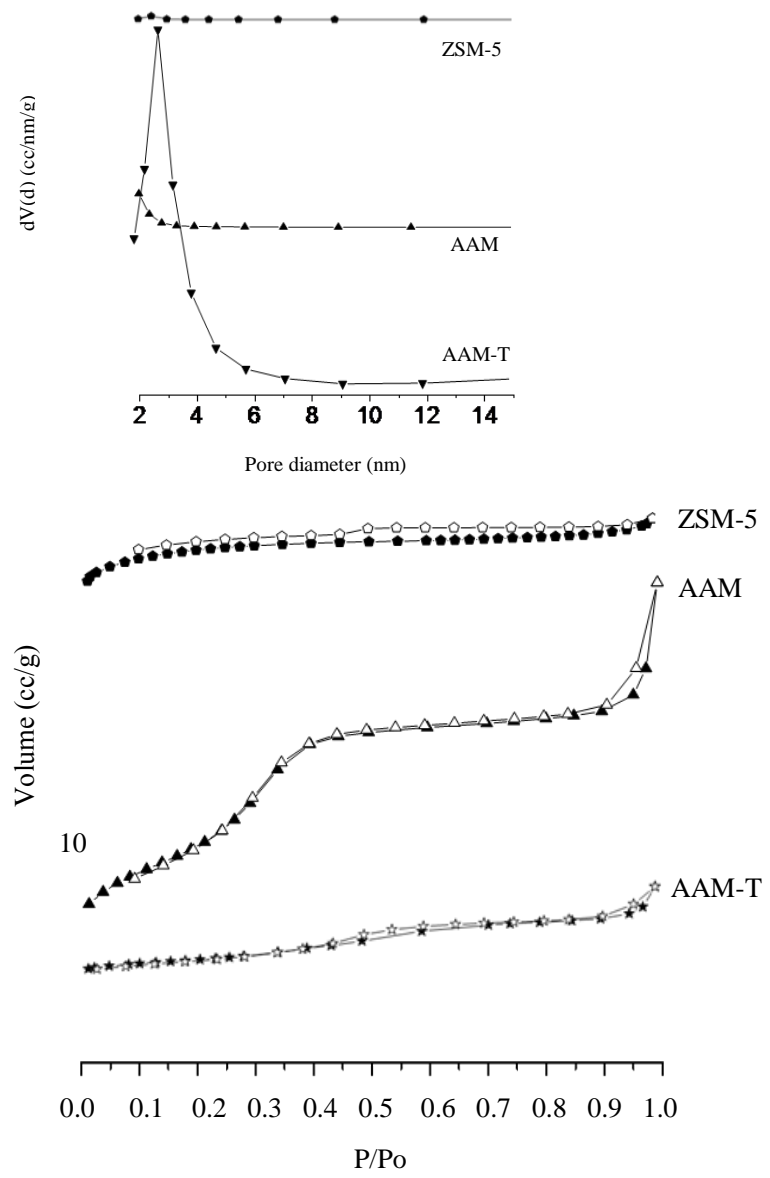

Figure 3 Nitrogen adsorption/desorption isotherm and pore size distribution of the AAM-T, AAM, and ZSM-5 
Table 1 Pore structure properties and acidity of catalysts

\begin{tabular}{|c|c|c|c|c|c|c|c|c|c|c|c|}
\hline \multirow{3}{*}{ Catalysts } & \multirow{3}{*}{$\begin{array}{l}\text { Si/Al } \\
\text { Mole } \\
\text { Ratio }^{\text {a }}\end{array}$} & \multirow{2}{*}{\multicolumn{2}{|c|}{$\begin{array}{l}\text { Structure-directing } \\
\text { agents }\left(\text { SDA) }{ }^{\mathbf{b}}\right.\end{array}$}} & \multirow{3}{*}{$\begin{array}{c}\text { Mesoporous } \\
\text { Surface } \\
\text { Area }^{\mathrm{c}} \\
\left(\mathbf{m}^{2} / \mathrm{g}\right)\end{array}$} & \multirow{3}{*}{$\begin{array}{l}\text { Microporous } \\
\text { Surface Area }^{\mathrm{d}} \\
\left(\mathrm{m}^{2} / \mathrm{g}\right)\end{array}$} & \multirow{3}{*}{$\begin{array}{l}\text { Pore } \\
\text { Volume }^{\mathrm{c}} \\
\text { (cc/g) }\end{array}$} & \multirow{3}{*}{$\begin{array}{c}\text { Pore } \\
\text { Diameter } \\
(\mathbf{n m})\end{array}$} & \multicolumn{4}{|c|}{ moi/g) } \\
\hline & & & & & & & & \multicolumn{2}{|c|}{ Brønsted } & \multicolumn{2}{|c|}{ Lewis } \\
\hline & & 1 & 2 & & & & & $150^{\circ} \mathrm{C}$ & $300^{\circ} \mathrm{C}$ & $150^{\circ} \mathrm{C}$ & $300^{\circ} \mathrm{C}$ \\
\hline ZSM-5 & 6.44 & ТРАВ & - & 5.77 & 256.03 & 0.01 & 3.82 & 1.53 & 1.24 & 0.95 & 0.84 \\
\hline AAM & 19.71 & ТРАOH & CTAB & 145.99 & 395.43 & 0.31 & 3.06 & 1.29 & 0.78 & 1.19 & 1.00 \\
\hline AAM-T & 24.62 & - & CTAB & 278.77 & 6.18 & 0.44 & 3.82 & 0.00 & 0.00 & 1.05 & 0.87 \\
\hline
\end{tabular}

a) determined by EDX

b) MFI structure template (1) and mesophase forming agent (2)

${ }^{c}$ ) determined by $\mathrm{BJH}$

$\left.{ }^{d}\right)$ determined by BET method at $\mathrm{P} / \mathrm{P}_{0}=0.3$

e) calculated from the IR spectra of adsorbed pyridine

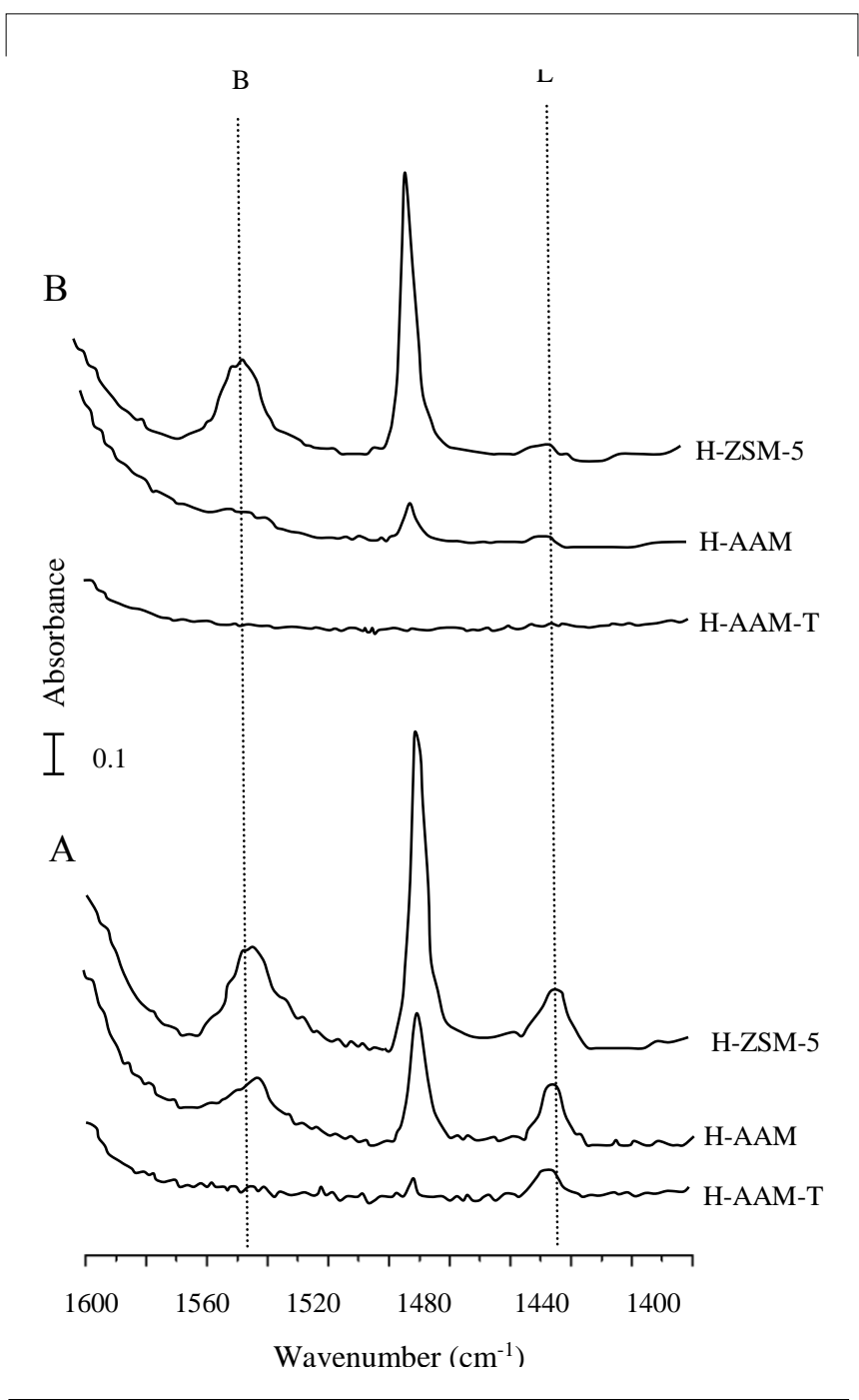

Figure 4 FTIR spectra of pyridine desorption on H-AAM-T, H-AAM, and $\mathrm{H}-\mathrm{ZSM}-5$ at $150{ }^{\circ} \mathrm{C}(\mathrm{A})$ and $300{ }^{\circ} \mathrm{C}(\mathrm{B})$
Acidic properties of H-AAM-T, H-AAM, and H-ZSM-5 catalysts were determined by FTIR spectroscopy using pyridine as the probe molecule. Figure 4 shows the FTIR spectra after pyridine desorption at 150 and $300{ }^{\circ} \mathrm{C}$. The band at around 1444 $\mathrm{cm}^{-1}$ corresponds to the chemisorption of pyridine $(\mathrm{C}-\mathrm{C}$ stretching of a coordinatively bonded pyridine complex) on Lewis (L) acid sites. The band at around $1544 \mathrm{~cm}^{-1}$ is attributed to the $\mathrm{C}-\mathrm{C}$ stretching vibration of the pyridinium ion and has been used to identify the presence of Brønsted (B) acid sites [25, 26]. The intensity of these bands show a significant reduction when the desorption temperature was increased to $300{ }^{\circ} \mathrm{C}$. This effect can be clearly seen on Brønsted acid sites due to the interaction between pyridine and Brønsted acid sites that are relatively weaker than Lewis acid sites (Table 1). Unlike HZSM-5 and H-AAM, there is no band observed at around 1544 $\mathrm{cm}^{-1}$ for H-AAM-T, indicating that the sample has low acid strength. The pyridine adsorption studies reveal that H-AAM catalyst has strong acid sites with both Lewis and Bronsted acid sites observed in the structure.

\subsection{Catalytic Activity}

The activity of the catalysts were evaluated on the acetalization of 3,4-dimethoxybenzaldehyde with propylene glycol. The reaction was conducted at $106{ }^{\circ} \mathrm{C}$ using toluene as the solvent. This reaction requires a strong acid catalyst and due to the bulky structure of the chemical reactant, a large mesoporous channel is important to allow the reactant to reach the active acid site in the catalysts. Figure 5 shows the conversion of 3,4-dimethoxybenzaldehyde within 4 hours of reaction using H-AAM, HAAM-T and H-ZSM-5 as catalysts. H-AAM is the most active catalysts with $50 \%$ of conversion within 15 minutes into the reaction. The importance of active acid sites for the reaction can be seen by no conversion of 3,4-dimethoxybenzaldehydeon $\mathrm{H}$ AAM-T catalysts. However, H-ZSM-5 was found inactive for this reaction despite considerable amount of acid sites observed on the catalysts surface. This implies the active acid sites are indeed located inside the pores of the zeolite structure. The micro size of the pores in H-ZSM-5 framework inhibits the reactant to reach the reaction sites and therefore no catalytic activity was observed. H-AAM catalyst with mesoporous structure provides an access for a bulky reactant to reach active acid sites for the reaction. Propylene glycol acetal of 3,4dimethoxybenzaldehyde was observed as the only product from the reaction on H-AAM. After $4 \mathrm{~h}$ of reaction, the conversion of 3,4-dimethoxy-benzaldehyde was found to be around $81.55 \%$ with no other product was detected to give a $100 \%$ selectivity towards desired product. However, analysis using GC-MS 
indicates the formation of as stereo-isomer structure in the acetal product.

The high conversion of 3,4-dimethoxybenzaldehyde to acetal is observed on the H-AAM catalysts. The presence of a strong Brønsted and Lewis acid site and a high mesostructured surface area in H-AAM catalyst are crucially important to catalyse the reaction (Table 1). This result proved the important role played by acid sites, the surface area of mesoporous framework and hierarchical porous of H-AAM on the acetalization reaction involving bulky materials.

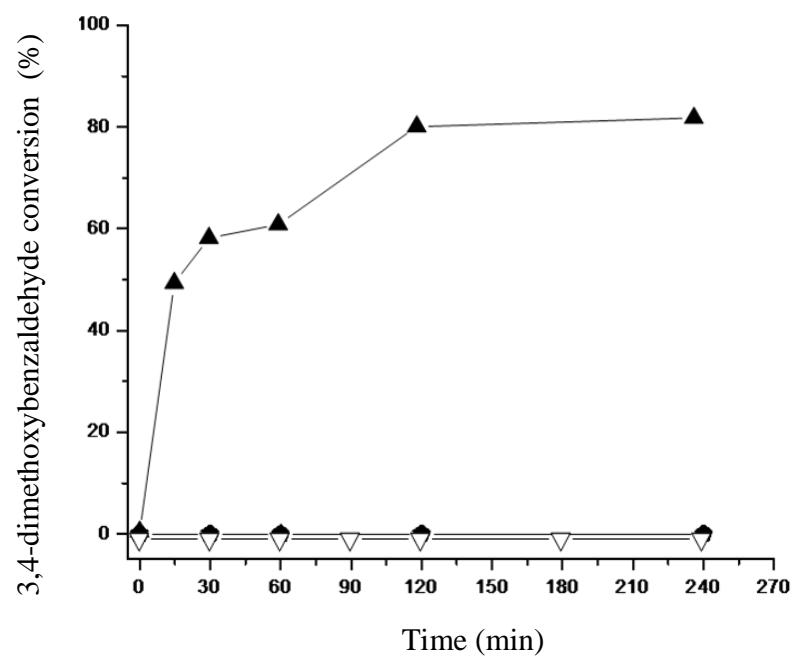

Figure 5 Time conversion plot of 3,4-dimethoxybenzaldehyde to acetal in the presence of H-AAM $(\boldsymbol{\Delta})$, H-AAM-T $(\nabla)$, or H-ZSM-5 $(\bullet)$ as a catalyst

\subsection{Mechanism for Acetalization}

General reaction for acetalization of aldehydes is initiated in the presence of an acid catalyst. Scheme 1 illustrates the proposed reaction mechanism of 3,4-dimethoxybenzaldehyde with propylene glycol. In the first step of reaction, the formation of carbocation on the carbonyl group of 3,4-dimethoxybenzaldehyde takes place on the Brønsted acid sites associated with tetrahedrally coordinated aluminium. Then, the carbocationic species were combined with nucleophilic oxygen of propylene glycol. Hemiacetals (1) was formed after deprotonation, which then subsequently reacts with hydroxyl group on propylene glycol. This is followed by the cyclodehydration to eliminate water molecule and produced 2-(3,4-dimethoxy-phenyl)-4methyl-1,3-dioxolane (2) [7].

\subsection{CONCLUSION}

The use of two structure directing agent, TPAOH and CTAB, on the synthesis of amorphous mesoporous aluminosilicate produced a highly active catalysts for acetalization of 3,4dimethoxybenzaldehyde. We managed to improve the existing procedure for synthesizing aluminosilicate and ZSM-5 to create a hierarchical porous structured aluminosilicate. The acidity of the catalyst and the mesoporous structure of the aluminosilicate framework are crucial factors to ensure high conversion and selectivity towards the acetalization reaction.

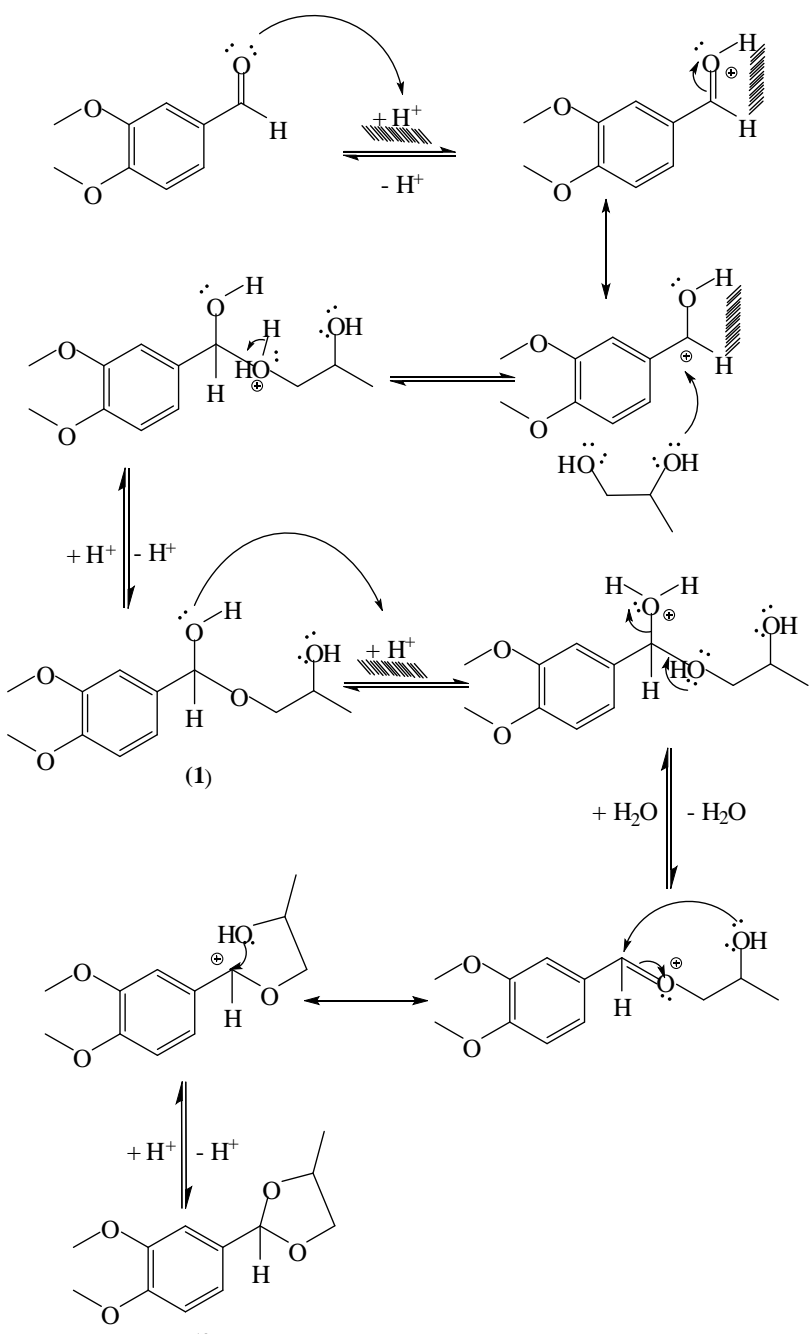

(2)

Scheme 1 Mechanism for the formation of 3,4-dimethoxybenzaldehyde propylene glycol acetal

Acknowledgement

The authors gratefully acknowledge the financial support from Ministry of Education and Culture, Indonesia, under "Unggulan" research.

\section{References}

[1] M. J. Climent, A. Corma, A. Velty. 2004. Synthesis of Hyacinth, Vanilla, and Blossom Orange Fragrances: The Benefit of Using Zeolites and Delaminated Zeolites As Catalysts. Appl. Catal. A. 263 $155-161$.

[2] J. Justus, A. Vinu, B.M. Devassy, V.V. Balasubramanian, W. Bohringer, J. Fletcher, S.B. Halligudi. 2008. Highly Efficient and Chemo Selective Catalyst System for the Synthesis of Blossom Orange Fragrance and Flavouring. Catal. Commun. 9: 1671-1675.

[3] S. B. Umbarkar, T. V. Kotbagi, A. V. Biradar, R. Pasrich, J. Chanale, M. K. Dongare, A.S. Mamede, C. Lancelot, E. Payen. 2009. Acetalization of Glycerol Using Mesoporous $\mathrm{MoO}_{3} / \mathrm{SiO}_{2}$ Solid Acid Catalyst. J. Mol. Catal. A: Chem. 310: 150-158.

[4] K. Venkatachalam, M. Palanichamy, V. Murugesan. 2010 Acetalization of Heptanal over Al-SBA-1 Molecular Sieve. Catal. Commun. 12: 299-303.

[5] M.J. Climent, A. Corma, A. Velty, M. Susarte. 2000. Zeolites for the Production of Fine Chemicals: Synthesis of the Fructone Fragrancy. $J$. 
Catal. 196: 345-351.

[6] L. XueZheng, G. Shan, W. WenJuan, C. WenPing, Y. Jian Guo. 2007. Comparative Research on the Catalytic Activities of Different Molecular sieves for Acetalization and Ketalization, Chin. Sci. Bull. 52(13): 1780-1784.

[7] S. Ajaikumar, A. Pandurangan. 2008, Reaction of Benzaldehyde with Various Aliphatic Glycols in the Presence of Hydrophobic Al-AAM-T41: A Convenient Synthesis of Cyclic Acetals, J. Mol. Catal. A: Chem. 290: $35-43$

[8] L. L Santos, V.R. Ruiz, M. J. Sabater, A. Corma. 2008. Regioselective Transformation of Alkynes Into Cyclic Acetals and Thioacetals with a Gold(I) Catalyst: Comparison with Brønsted Acid Catalysts. Tetrahedron. 64: 7902-7909.

[9] I. Karame', M. Alame', A. Kanj, G.N. Baydoun, H. Hazimeh, M. el Masri, L. Christ. 2011. Mild and Efficient Protection of Diol and Carbonyls as Cyclic Acetals Catalysed by Iron (III) Chloride. C. R. Chimie. 14: 525-529.

[10] M. S. Khayoon, A. Abbas, B. H. Hameed, S. Triwahyono, A. A. Jalil, A.T. Haris, A.I. Minett. 2014. Selective Acetalization of Glycerol with Acetone Over Nickel Nanoparticles Supported on Multi-Walled Carbon Nanotubes. Catal. Lett. 144: 1009-1015.

[11] R.R. Pawar, S.V. Jadhav, C.H. Bajaj. 2013. Microwave-assisted Rapid Valorization of Glycerol Towards Acetals and Ketals. Chem. Eng. J. 235: 61-66.

[12] B. Thomas, F.G. Ramu, S. Gopinath, J. George, M. Kurian, G. Laurent, G.L. Drisko, S. Sugunan. 2011. Catalytic Acetalization of Carbonyl Compounds Over Cation $\left(\mathrm{Ce}^{3+}, \mathrm{Fe}^{3+}\right.$ and $\left.\mathrm{Al}^{3+}\right)$ Exchanged Mont-morillonites and $\mathrm{Ce}^{3+}$-exchanged Y Zeolites. Appl. Clay Sci. 53 227-235.

[13] A.O. Barros, A.T. Faísca, E.R.. Lachter, R.S.V. Nascimento, R.A.S SanGil, J. Braz. 2011. Acetalization of Hexanal with 2-Ethyl Hexanol Catalyzed by Solid Acids. Chem. Soc. 22(2): 359-363.

[14] V.N. Shetti, J. Kim, R. Srivastava, M. Choi, R. Ryoo. 2008. Assesment of the Mesopore Wall Catalytic Activities of MFI Zeolite with Mesoporous/Microporous Hierarchical Structures. J. Catal. 254 296-303.

[15] R. Bruckner. 2010. Organic Mechanisms Reactions, Stereochemistry and Synthesis. Springer-Verlag, Berlin Heidelberg.
[16] I. Rodriguez, M.J. Climent, S. Iborra, V. Fornds, A. Corma, A. 2000. Use of Delaminated Zeolites (ITQ-2) and Mesoporous Molecular Sieves in the Production of Fine Chemicals: Preparation of Dimethylacetals and Tetrahydropyranylation of Alcohols and Phenols. J. Catal. 192: 441-447.

[17] M.L. Goncalves, L.D. Dimitrov, M.H. Jorda, M. Wallau, A. Ernesto, U. Gonzalez. 2008. Synthesis of Mesoporous ZSM- 5 by Crystallisation of Aged Gels in the Presence of Cetyltrimethylammonium Cations. Catal. Today. 133-135: 69-79.

[18] G. A. Eimer, I. Diaz, E. Sastre, G. S. Casuscelli, M. E. Crivello, E. R. Herrero, J. Periente,J. 2008. Mesoporous Titanosilicates Synthesized from TS-1 Precursors with Enhanced Catalytic Activity in the $\alpha$-pinene Selective Oxidation. Appl. Catal. A. 343: 77-86.

[19] Y. Cheng, L. J. Wang, J.S. Li, Y.C. Yang, X.Y. Sun. 2005. Preparation and Characterization of Nanosized ZSM-5 Zeolites in the Absence of Organic Template. Mater. Lett. 59: 3427-3430.

[20] C. A. Emeis. 1993. Determination of Integrated Molar Extinction Coefficients for Infrared Absorption Bands of Pyridine Adsorbed on Solid Acid Catalysts. J. Catal. 141(2): 347-354.

[21] K. N. Tayade, M. M. K. Munusamy, R.S. Somani. 2014. Solvent Free Acid Catalyzed Direct N-Alkylation of Amines with Alcohols using Al Grafted AAM-T-41. J. Mol. Catal. A: Chem. In Press.

[22] S. Meenakshi, A.K. Sahu, S.D. Bhat, P. Sridhar, S. Pitchumani, A.K. Shukla. 2013. Mesostructured-aluminosilicate-Nafion Hybrid Membranes for Direct Methanol Fuel Cells. Electrochim. Acta. 89: 3544.

[23] J. Yang, S. Yu, H. Hu, Y. Zhang, J. Lu, J. Wang, D. Yin. 2011 Synthesis of ZSM-5 Hierarchical Microsphere-like Particle by Two Stage Varying Temperature Crystallization without Secondary Template. Chem. Eng. J. 166: 1083-1089.

[24] M. Thommes. 2010. Physical Adsorption Charac-terization of Nanoporous Materials. Chemie Ingenieur Technik. 82(7) 1059-1073.

[25] F. Jin and Y. Li. 2009. A FTIR and TPD examination of the distributive properties of acid sites on ZSM-5 zeolite with pyridine as a probe molecule. Catal. Today. 145: 101-107.

[26] E. J. M. Hense, D. G. Poduval, V. Degirmenci, D. A. J. M. Ligthart, W. Chen, F. Maugé, M. S. Rigutto, J. A. R. van Veen. 2012. Acidity Characterization of Amorphous Silica-Alumina. J. Phy. Chem. C. 116: 21416-21429. 